\title{
Hydrogeochemical characterization of a shallow groundwater system in the weathered basement aquifer of Ilesha area, southwestern Nigeria
}

\author{
MOSHOOD N. TIJANI ${ }^{1}$, SAHEED A. OKE ${ }^{2} \&$ AKINYEMI T. OLOWOOKERE \\ 1 Department of Geology, University of Ibadan, Ibadan, Nigeria \\ tmoshood@gmail.com; mn.tijani@ui.edu.ng \\ 2 Department of Chemical and Geological Sciences, Al-Hikmah University, Ilorin, Nigeria
}

\begin{abstract}
Hydrogeochemical characterization of a weathered basement aquifer in Ilesha area, southwest Nigeria, was carried out with respect to geogenic and anthropogenic influences on the shallow groundwater system. Physico-chemical parameters revealed a $\mathrm{pH}$ of $6.4-8.4$ and EC of $22-825 \mu \mathrm{s} / \mathrm{cm}$ in the urban areas compared to a $\mathrm{pH}$ of 7.3-10.5 and relatively higher EC of 126-1027 $\mu \mathrm{s} / \mathrm{cm}$ in the peri-urban area. The concentrations of major cations $(\mathrm{Ca}, \mathrm{Na}, \mathrm{K}, \mathrm{Mg})$ in the urban areas revealed relatively lower average concentrations of $28.4,16.7,8.4$ and $5.0 \mathrm{mg} / \mathrm{L}$, respectively, compared to $82.5,33.4,19.3$ and $12.4 \mathrm{mg} / \mathrm{L}$, respectively, for the peri-urban areas. The low concentrations of major cations in the urban areas can be attributed to low mineral dissolution of quartzite and muscovite quartz-schist bedrocks compared to the weathered granitic, amphibolite and biotite schist in the peri-urban areas. Hydrochemical characterization revealed two main water types; namely $\mathrm{Ca}-\mathrm{Mg}-(\mathrm{Na})-\mathrm{HCO}_{3}$ mostly in the urban areas suggesting $\mathrm{CO}_{2}$-charged infiltrating recharge rainwater, and $\mathrm{Ca}-\mathrm{Na}-(\mathrm{K})-\mathrm{SO}_{4}-\mathrm{Cl}$ type in the peri-urban areas as products of water-rock interactions.
\end{abstract}

Key words groundwater; crystalline basement; weathered aquifer; hydrochemical characterization; water quality

\section{INTRODUCTION}

There is no doubt as to the fact that shallow groundwater plays an important role in domestic, agricultural and industrial water supplies in developing countries like Nigeria. This is consequent to the fact that such shallow groundwater systems, especially in the crystalline basement terrains, can be relatively easily tapped with minimal cost, and are a timely assured source compared to surface water development, especially in rural communities (Rao 2006, Fashae et al. 2013).

However, the quality of such groundwater systems is increasingly being endangered by urbanization and industrial activities, along with the emerging threat of impacts of climatic changes. This can be partly attributed to uncontrolled population growth, poor urban planning and associated poor sanitary infrastructure, as found in many developing nations, like Nigeria. In addition, due to the physico-chemical and biochemical interaction between groundwater and anthropogenic contaminants along geogenic water-rock interactions, there is the need for proper understanding of the nature of both anthropogenic and geogenic drivers of groundwater quality, especially under a shallow weathered basement aquifer setting.

Consequently, this study focuses on the hydrogeochemical characterization of shallow groundwater in the weathered basement aquifer of Ilesha Area, south-western, Nigeria, with reference to impacts of urbanization and geogenic water-rock interactions. In addition, the erratic nature of groundwater occurrence in crystalline rocks of the study area also warrants proper understanding of the hydrogeochemical characterization of the associated shallow groundwater system.

\section{LOCATION AND HYDROGEOLOGIC SETTING OF THE STUDY AREA}

The study area encompasses Ilesha township and its environs between latitudes $7^{\circ} 25^{\prime}$ and $7^{\circ} 45^{\prime} \mathrm{N}$ and longitudes $4^{\circ} 35^{\prime}$ and $4^{\circ} 5^{\prime} \mathrm{E}$, respectively, and covers approximately $900 \mathrm{~km}^{2}$ (Fig. 1). The study area, situated in southwestern Nigeria included Ilesha town as the urban / commercial centre and the adjoining villages and smaller settlements, as peri-urban areas. The area falls in the tropical rainforest zone, with distinct wet and dry climatic seasons characterized by mean annual rainfall of $1000-1500 \mathrm{~mm}$, mean annual temperature of $26-31^{\circ} \mathrm{C}$ and humidity of $75-95 \%$. 
Geologically, the study area lies within the so-called Ilesha Schist Belts Complex of southwest Nigeria, characterized by gneiss-migmatite complex, the metasedimentary assemblages, the amphibolite complex and the granitic rocks units (Elueze 1982). The rock units in Ilesha urban centre include muscovite schist and quartzite schist, while the peri-urban areas are characterized by granitegneiss, hornblende gneiss and biotite-schist (Fig. 1). Hydrogeologically, the groundwater occurrences are in localized weathered regolith aquifers, which are generally discontinuous and essentially under phreatic unconfined to semi-confined conditions, as in the case of most crystalline bedrock settings in Nigeria (Tijani 1994).

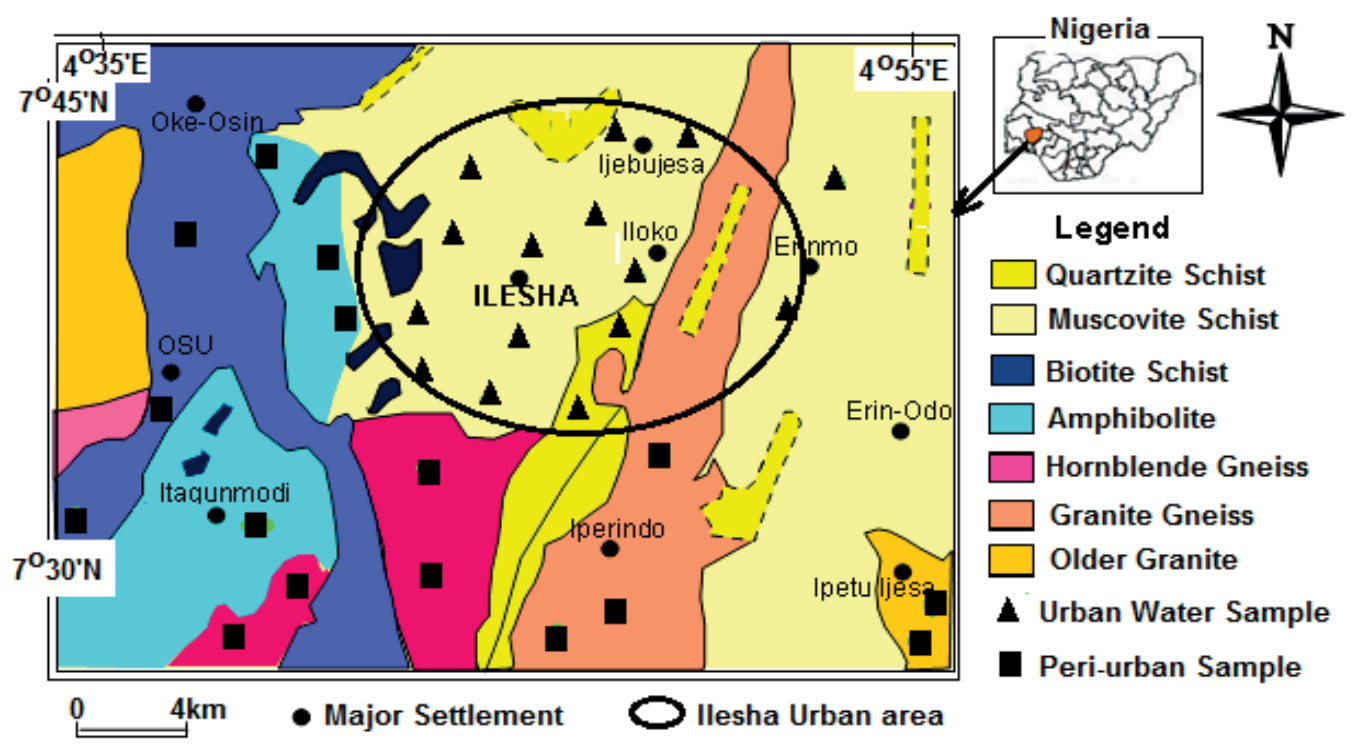

Fig. 1 Geological map of the Ilesha area showing sampling points.

\section{METHODOLOGY}

A total of 21 representative water samples were collected from shallow hand-dug wells following standard procedures; including 10 samples from the urban area of Ilesha and 11 samples from the surrounding peri-urban areas. The sampling was done across the different rock types of the study area. In addition to the well inventories (e.g. well depth, water level, etc.), sensitive physicochemical parameters such as electrical conductivity (EC), $\mathrm{pH}$, temperature and total dissolves solids (TDS) were measured in situ in the field.

Laboratory analyses include measurements of cations using inductive couple plasma mass spectrometers (ICP/MS), while anions were measured using titrimetric methods. Subsequent data evaluation involved quality assessment with respect to drinking water standards, as well as statistical evaluation involving correlation and hydrochemical characterization using Piper (1944) trilinear plots and Schoeller (1962) diagrams.

\section{RESULTS AND ANALYSIS}

\section{Field measurements and hydrochemical analyses}

The inventory of the study shallow-dug wells revealed a depth range of 3.6-13.8 m (average $9.0 \mathrm{~m}$ ) and water level depth of 1.4-11.3 m characterized by small water columns typical of dug-wells in basement terrain. The field in situ measurements revealed EC of $22-825 \mu \mathrm{s} / \mathrm{cm}$ (average $212 \mu \mathrm{s} / \mathrm{cm}$ ) and pH 6.4-8.4 (average 7.3) suggesting a neutral to slight alkaline waters for the Ilesha urban areas compared to moderately high EC of 126-1027 $\mu \mathrm{s} / \mathrm{cm}$ (average $504 \mu \mathrm{s} / \mathrm{cm}$ ) and $\mathrm{pH}$ of $7.3-10.5$ (average 8.2) for the peri-urban areas suggesting moderately alkaline water.

Major cations concentrations are in the order of $\mathrm{Ca}>\mathrm{Na}>\mathrm{K}>\mathrm{Mg}$ with average values of 28.4, $16.7,8.4$ and $5.0 \mathrm{mg} / \mathrm{L}$, respectively, for the urban areas and $82.5,33.0,19.3$ and $12.4 \mathrm{mg} / \mathrm{L}$, 
Hydrogeochemical characterization of shallow groundwater system in the weathered basement 477

Table 1 Summary of well inventory and hydrochemical analyses results of water samples from the study area.

\begin{tabular}{|c|c|c|c|c|c|c|c|}
\hline \multirow[t]{2}{*}{ Parameters } & \multicolumn{3}{|c|}{ Ilesha Urban Area $(\mathrm{N}=10)$} & \multicolumn{3}{|c|}{ Peri-urban Area $(\mathrm{N}=11)$} & \multirow{2}{*}{$\begin{array}{l}\text { WHO \&SON } \\
\text { Standards }\end{array}$} \\
\hline & Min. & Max. & Mean & Min. & Max. & Mean & \\
\hline Well Depth (m) & 4.5 & 11.3 & 8.4 & 1.4 & 11.0 & 6.6 & \\
\hline $\operatorname{DTWL}(\mathrm{m})$ & 6.4 & 11.8 & 9.6 & 3.6 & 13.8 & 8.4 & \\
\hline Temp. $\left({ }^{\circ} \mathrm{C}\right)$ & 26.2 & 28.7 & 27.5 & 26.6 & 29.9 & 28.4 & Variable \\
\hline $\mathrm{pH}$ & 6.4 & 8.4 & 7.3 & 7.3 & 10.5 & 8.2 & $6.5-9.5$ \\
\hline $\mathrm{EC}(\mu \mathrm{S} / \mathrm{cm})$ & 22.0 & 825.0 & 212.3 & 126.0 & 1027.0 & 503.5 & $400-1400$ \\
\hline $\mathrm{TDS}(\mathrm{mg} / \mathrm{L})$ & 16.5 & 618.8 & 159.2 & 94.5 & 770.3 & 377.7 & $300-1000$ \\
\hline $\mathrm{TH}\left(\mathrm{mg} / \mathrm{LCaCO}_{3}\right)$ & 3.0 & 90.2 & 23.1 & 11.6 & 135.8 & 54.9 & $<500.0$ \\
\hline $\operatorname{SAR}(\mathrm{meq} / \mathrm{L})$ & 0.2 & 2.1 & 0.8 & 0.3 & 1.7 & 0.9 & \\
\hline $\mathrm{Ca}^{2+}(\mathrm{mg} / \mathrm{L})$ & 2.7 & 117.8 & 28.4 & 16.9 & 250.8 & 82.5 & $75-200$ \\
\hline $\mathrm{Mg}^{2+}(\mathrm{mg} / \mathrm{L})$ & 0.9 & 17.8 & 5.0 & 1.6 & 21.8 & 12.4 & $20-150$ \\
\hline $\mathrm{Na}^{+}(\mathrm{mg} / \mathrm{L})$ & 2.4 & 72.4 & 16.7 & 4.4 & 86.6 & 33.0 & $20-200$ \\
\hline $\mathrm{K}^{+}(\mathrm{mg} / \mathrm{L})$ & 1.8 & 32.6 & 8.4 & 1.8 & 49.3 & 19.3 & $10-12$ \\
\hline $\mathrm{HCO}_{3}{ }^{-}(\mathrm{mg} / \mathrm{L})$ & 12.2 & 91.5 & 33.6 & 18.7 & 112.0 & 60.0 & Variable \\
\hline $\mathrm{Cl}^{-}(\mathrm{mg} / \mathrm{L})$ & 3.1 & 64.8 & 18.9 & 18.0 & 86.4 & 39.0 & 600 \\
\hline $\mathrm{NO}_{3}^{-}(\mathrm{mg} / \mathrm{L})$ & 0.0 & 1.2 & 0.4 & 0.0 & 0.7 & 0.3 & 50 \\
\hline $\mathrm{SO}_{4}^{-2}(\mathrm{mg} / \mathrm{L})$ & 0.0 & 1.7 & 0.9 & 0.0 & 2.9 & 1.1 & 400 \\
\hline $\mathrm{Cd}(\mu \mathrm{g} / \mathrm{L})$ & 0.3 & 6.1 & 2.3 & 0.1 & 2.5 & 0.9 & 3.0 \\
\hline $\mathrm{Co}(\mu \mathrm{g} / \mathrm{L})$ & 0.1 & 5.6 & 1.5 & 0.0 & 3.3 & 0.6 & \\
\hline $\mathrm{Cr}(\mu \mathrm{g} / \mathrm{L})$ & 0.5 & 16.4 & 3.0 & 0.8 & 10.8 & 2.8 & 50 \\
\hline $\mathrm{Cu}(\mu \mathrm{g} / \mathrm{L})$ & 1.8 & 8.6 & 4.3 & 0.9 & 9.3 & 3.3 & 200 \\
\hline $\mathrm{Ni}(\mu \mathrm{g} / \mathrm{L})$ & 2.1 & 15.0 & 8.5 & 1.3 & 19.0 & 4.5 & 20 \\
\hline $\mathrm{Pb}(\mu \mathrm{g} / \mathrm{L})$ & 1.7 & 4.8 & 3.1 & 0.9 & 4.4 & 2.2 & 10 \\
\hline $\mathrm{Zn}(\mu \mathrm{g} / \mathrm{L})$ & 26.2 & 245.4 & 95.9 & 12.2 & 792.8 & 149.8 & 300 \\
\hline
\end{tabular}

WHO (1993) - Guidelines for drinking water quality; SON (2007) - Standard Organization of Nigeria; Drinking water quality standards; DTWL = depth to water level; SAR = Sodium adsorption ratio.

respectively, for the peri-urban areas (Table 1). Bicarbonate and chloride are the dominant anions with average concentrations of 33.6 and $18.9 \mathrm{mg} / \mathrm{L}$, respectively, for the urban areas and 60.0 and $39.0 \mathrm{mg} / \mathrm{L}$, respectively, for the peri-urban areas, while other anions like $\mathrm{NO}_{3}$ and $\mathrm{SO}_{4}$ are generally less than $2 \mathrm{mg} / \mathrm{L}$ in both settings.

The concentrations of trace metals $(\mathrm{Cd}, \mathrm{Co}, \mathrm{Cr}, \mathrm{Cu}, \mathrm{Ni}$ and $\mathrm{Pb})$ are generally low, with values of less than $10 \mu \mathrm{g} / \mathrm{L}$ in both urban and peri-urban areas. However, with the exception of $\mathrm{Zn}$, the trace metal profiles exhibit slight enrichment with average values of $1.5-8.5 \mu \mathrm{g} / \mathrm{L}$ for the water samples from the urban setting, suggesting anthropogenic impacts, compared to average values of $0.6-4.5$ $\mu \mathrm{g} / \mathrm{L}$ for the peri-urban areas.

Further evaluation of the results revealed lower concentrations of the cations and anions in the urban areas with corresponding TDS of $16.5-619 \mathrm{mg} / \mathrm{L}$ compared to the relatively higher TDS of $94.5-770 \mathrm{mg} / \mathrm{L}$ for the peri-urban areas. These can be partly attributed to the slightly alkaline to moderately alkaline $\mathrm{pH}$ of groundwater from the peri-urban areas while the lower mineralization of the major ions in the urban areas can be attributed to low mineral dissolution of quartzite and muscovite quartz-schist bedrocks to weathering compared to the weathered granitic, amphibolite and biotite schist units in the peri-urban areas.

Furthermore, a plot of the major ions against the measured electrical conductivity (EC) also confirmed a relatively lower mineralization of the water from the urban areas compared to those of the peri-urban while the linear relationship as shown in Fig. 2 is a clear indication of the contribution of these ions to the overall total dissolved solids of the groundwater system.

\section{Quality and usability assessments}

The concentrations of the analysed major ions are within the recommended permissible level of both WHO and SON standards for drinking water. For the trace elements, with the exception of 

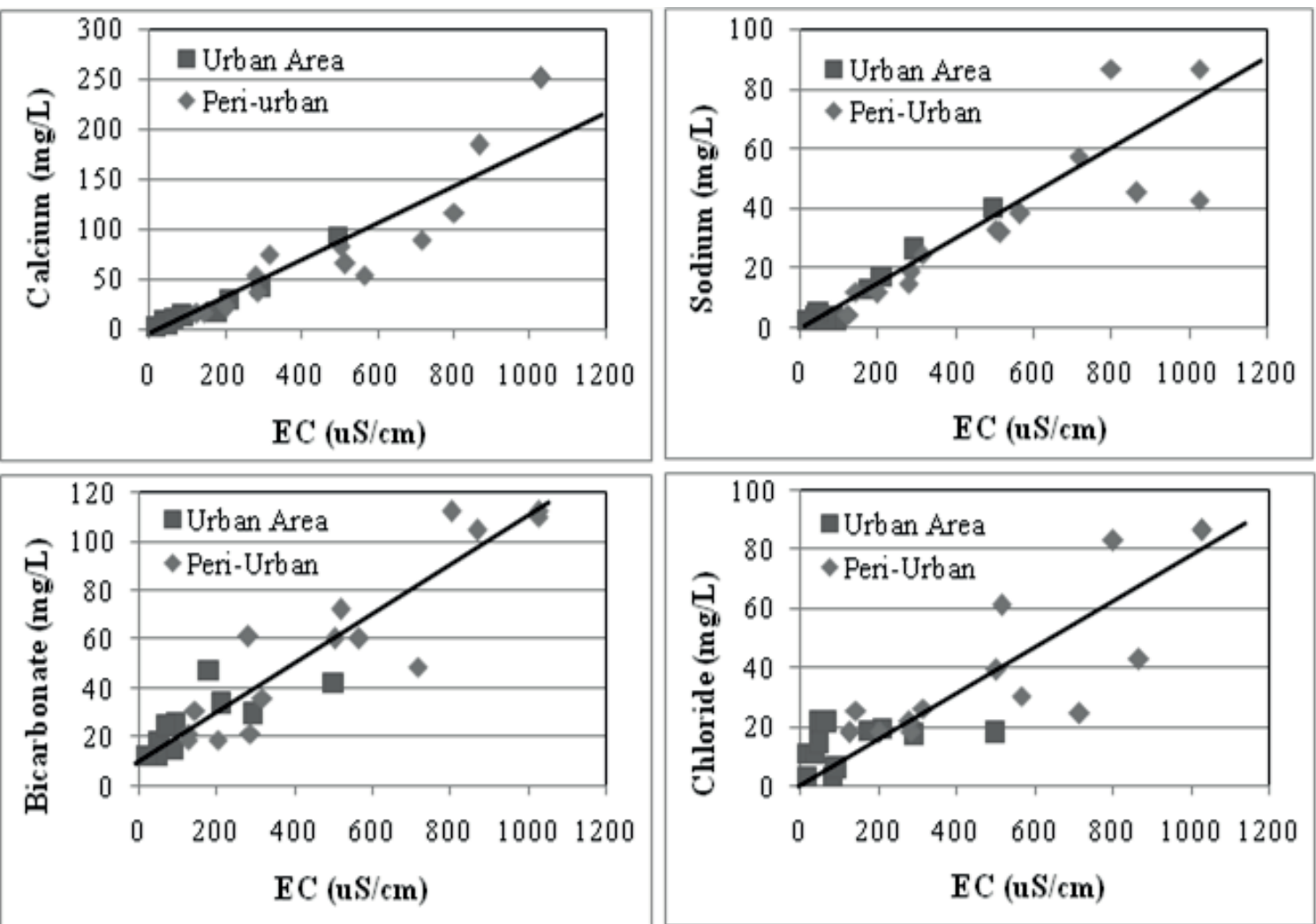

Fig. 2 Cross plots of the major ions against electrical conductivity measurements.

$\mathrm{Zn}$, all the analysed trace metals are within the permissible levels of WHO and SON. The overall implication is that the shallow groundwater system in the study area can be said to be chemically potable and suitable for domestic and household uses. However, the microbiological quality cannot be said to be totally satisfactory, due to the observed proximity of some dug-wells to pit latrines and septic tanks in some households, especially in the urban areas.

In terms of agricultural usage, the estimated sodium absorption ratio (SAR) of $0.31-2.1 \mathrm{meq} / \mathrm{L}$ falls within the range of $0-10 \mathrm{meq} / \mathrm{L}$ recommended for irrigation on most agricultural soils (USDA 1954, Sawyer and McCarthy 1967). In addition, the salinity hazard as well as the electrical conductivity (EC) and total dissolved solids (TDS) of the analysed groundwater satisfied the criteria for good irrigation water.

\section{Groundwater characterization}

The concept of hydrochemical facies was developed in order to understand and identify the hydrochemical evolution of water types using dominant ions in groundwater system (Freeze and Cherry 1979, Domenico and Schwartz 1990). Using Piper and Schoeller plots (Figs 3 and 4) shallow groundwater in the study area revealed two main water types; namely $\mathrm{Ca}-\mathrm{Mg}-(\mathrm{Na})-\mathrm{HCO}_{3}$ type mostly in the urban areas and $\mathrm{Ca}-\mathrm{Na}-(\mathrm{K})-\mathrm{SO}_{4}-\mathrm{Cl}$ type with subordinate $\mathrm{Na}-\mathrm{HCO}_{3}$ type in the periurban areas.

$\mathrm{Ca}-\mathrm{Mg}-(\mathrm{Na})-\mathrm{HCO}_{3}$ water type is a reflection of $\mathrm{CO}_{2}$-charged infiltrating recharge rainwater characterized by low mineralization due to limited migratory history, while $\mathrm{Ca}-\mathrm{Na}-(\mathrm{K})-\mathrm{SO}_{4}-\mathrm{Cl}$ and $\mathrm{Na}-\mathrm{HCO}_{3}$ water types are products of water-rock interactions and cation-exchange process within the weathered bedrock units of the peri-urban, which are characterized by varied weathered bedrock units. This agrees with other previous studies (Tijani 1994, Tijani and Abimbola 2003, Elueze et al. 2004) and it is believed to be common of water types in the basement aquifer of southwestern Nigeria. 


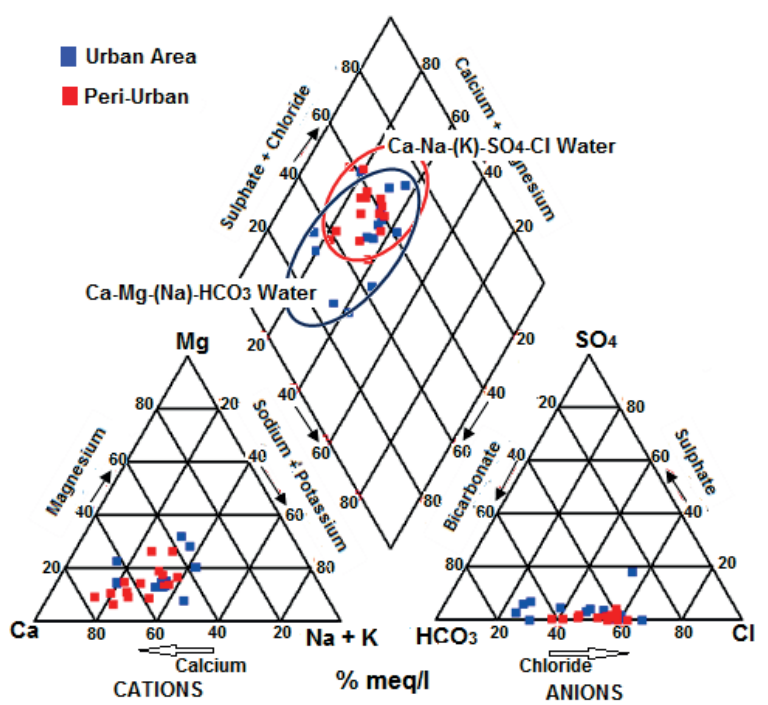

Fig. 3 Piper plots of water samples from the study area.
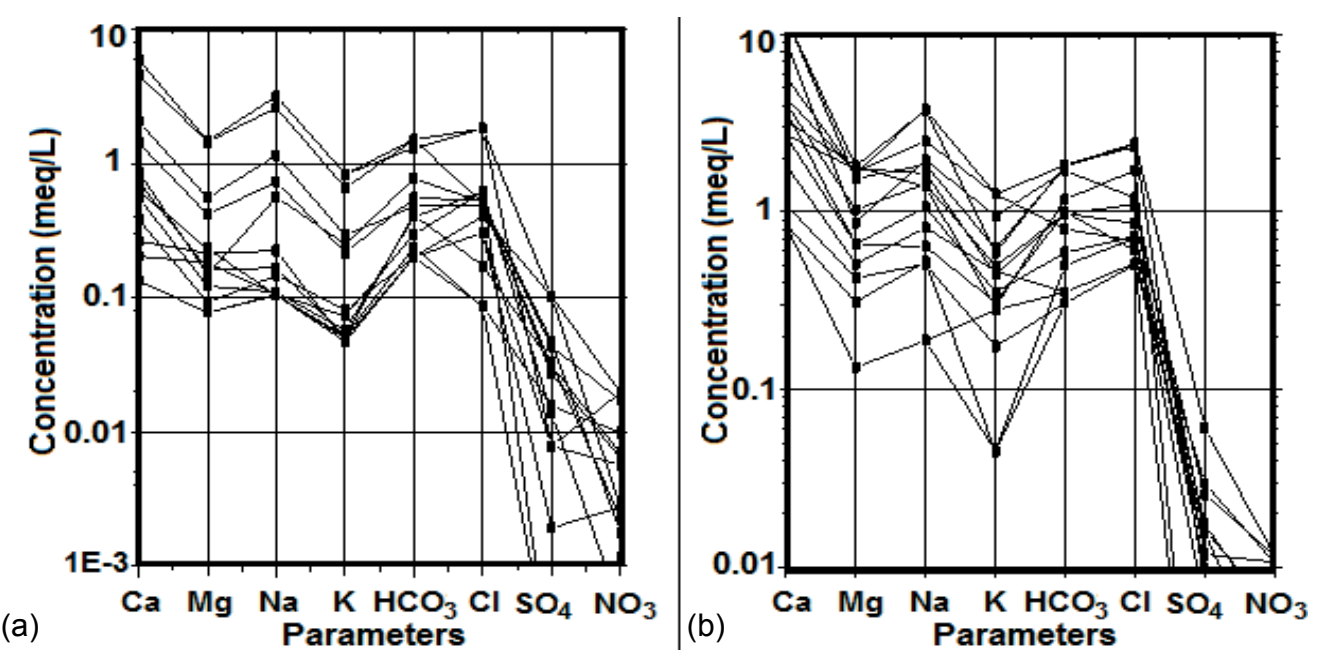

Fig. 4 Schoeller diagram for samples from urban (a) and peri-urban areas (b).

\section{SUMMARY AND CONCLUSIONS}

The concentrations of major ions and trace metals in the shallow groundwater system of Ilesha area, southwest Nigeria were evaluated and discussed with respect to anthropogenic and geogenic impacts in a typical weathered crystalline basement terrain. The physico-chemical parameters revealed slight to moderate alkaline waters in the peri-urban area, unlike the neutral to slight alkaline waters of the urban areas. Generally, the EC and TDS in the peri-urban areas are moderately higher compared to the urban areas, a situation attributed to the low weathering potential of the muscovite schist and quartzite schist in the urban areas of Ilesha compared to the relatively weathered biotite schist, amphibolite and granites that characterize the peri-urban areas.

Major cation concentrations are in the order of $\mathrm{Ca}>\mathrm{Na}>\mathrm{K}>\mathrm{Mg}$ with average values of 28.4, $16.7,8.4$ and $5.0 \mathrm{mg} / \mathrm{L}$, respectively, for the urban areas and 82.5, 33.0, 19.3 and $12.4 \mathrm{mg} / \mathrm{L}$, respectively, for the peri-urban areas. Bicarbonate and chloride are the dominant anions with average concentrations of 33.6 and $18.9 \mathrm{mg} / \mathrm{L}$, respectively, for the urban areas and 60.0 and $39.0 \mathrm{mg} / \mathrm{L}$, respectively, for the peri-urban areas. Trace metals $(\mathrm{Cd}, \mathrm{Co}, \mathrm{Cr}, \mathrm{Cu}, \mathrm{Ni}$ and $\mathrm{Pb})$ are generally low, with values of less than $10 \mu \mathrm{g} / \mathrm{L}$, with the exception of $\mathrm{Zn}$, which can be attributed to zinc-coated roofs. Nonetheless, slight enrichment with average values of $1.5-8.5 \mu \mathrm{g} / \mathrm{L}$ for the water samples from the urban setting is an indication of anthropogenic impacts, compared to average values of 0.6$4.5 \mu \mathrm{g} / \mathrm{L}$ for the peri-urban areas. 
In terms of usability, the analysed major ions and trace metals are within the recommended permissible level of both WHO and SON standards for drinking water, suggesting a chemically potable shallow groundwater system suitable for domestic and household uses. In addition, the estimated sodium absorption ratio (SAR) of $0.31-2.1 \mathrm{meq} / \mathrm{L}$ falls within the range of $0-10 \mathrm{meq} / \mathrm{L}$ recommended for irrigation on most agricultural soils. Nonetheless, a follow-up microbiological analysis is recommended to assess possible contamination of the dug-wells that are in close proximity of pit latrines and septic tanks in some households, as observed during the field sampling operation.

Water characterization revealed geogenic controls on the water chemistry with $\mathrm{Ca}-\mathrm{Mg}-(\mathrm{Na})-$ $\mathrm{HCO}_{3}$ water type in urban areas suggesting $\mathrm{CO}_{2}$-charged infiltrating rain water characterized by low mineralization and $\mathrm{Ca}-\mathrm{Na}-(\mathrm{K})-\mathrm{SO}_{4}-\mathrm{Cl}$ and $\mathrm{Na}-\mathrm{HCO}_{3}$ water types as products of water-rock interactions and cation-exchange process within the weathered bedrock units of the peri-urban, which are characterized by varied weathered bedrock units.

\section{REFERENCES}

Domenico, P. A. and Schwartz, F. W. (1990) Physical and Chemical Hydrogeology. John Wiley and Sons. 265 p.

Elueze, A. A. (1982) Geochemistry of Ilesha granite-gneiss in the basement complex of southwestern Nigeria. Precambra. Res. 19, 167177.

Elueze, A. A, Omidiran, J. O and Nton, M. E (2004) Hydrogeochemical investigation of surface and groundwater around Obokun, Olesha area, SW Nigeria. Journal Mining and Geology 40(1), 57-64.

Fashae, O. A., et al.(2014) Delineation of Groundwater potential zones in the crystalline basement terrain of SW-Nigeria: an integrated GIS and remote sensing approach. Applied Water Science 4, 19-38.

Freeze, R. A. and Cheery, J. A. (1979) Groundwater. Prentice-Hall, Englewood Cliffs, New Jersey, 604 p.

Piper, A. M. (1944) A graphical procedure in geochemical interpretation of water analysis. Trans. American Geophysics 914-923.

Rao, N. S. (2006) Groundwater potential index in a crystalline terrain using remote sensing data. Environ. Geol. 50:1067-1076.

Sawyer, C. N. and McCarthy, P. L. (1967) Chemistry for Sanitary Engineers. 2nd edn. McGraw-Hill, New York. 518 p.

Schoeller, H. (1962). Les eaux souterraines. Masson \& Cie, Paris 642 pp.

SON (2007) Nigerian Standards for Drinking Water Quality. Standard Organization of Nigeria (SON) Publ. NIS-554; 30 p.

Tijani, M. N. (1994) Hydrogeochemical assessment of groundwater in Moro area, Kwara State, Nigeria. Environ. Geol. 24(3), 194-202.

Tijani, M. N. \& Abimbola, A. F. (2003) Groundwater chemistry and isotope studies of weathered basement aquifer: a case study of Oke-Ogun area, SW Nigeria. Afric. Geosci. Rev. 10(4), 373-387.

US Department of Agriculture (1954) Diagnosis and Improvement of Saline and Alkaline Soils. Agricultural Handbook no. 60; USDA: Washington, DC.

WHO (1993) Guidelines for Drinking Water Ouality, 2nd edn, World Health Organization, Geneva, Switzerland. 